\title{
The ice-thickness distribution of Unteraargletscher, Switzerland
}

\author{
Andreas BAUDER, Martin FUNK, G. Hilmar GUDMUNDSSON* \\ Versuchsanstalt für Wasserbau, Hydrologie und Glaziologie (VAW), Eidgenössische Technische Hochschule, ETH-Zentrum, \\ CH-8092 Zürich, Switzerland \\ E-mail: bauder@vaw.baug.ethz.ch
}

\begin{abstract}
Results from 15 years of work on glacier-bed mapping by radio-echo soundings on Finsteraar-, Lauteraar- and Unteraargletscher, Switzerland, are summarized, and a new and greatly improved map of the ice-thickness distribution presented. In contrast to the tongue of Unteraargletscher, its two main tributaries, Lauteraar and Finsteraar, are both deep and narrow, and ice-thickness determination depends on the detection of more than just the primary reflection. Migrating the data led to considerably improved bed determination. Wherever possible, additional information on ice thicknesses gained from numerous hot-water drillings to the glacier bed is used as an independent verification of the results of the radar measurements, and a fair agreement is found.
\end{abstract}

\section{INTRODUCTION}

Knowledge of ice-thickness distribution is of fundamental interest to most glaciological studies. Radio-echo soundings are recognized as an efficient technique for mapping glacier bed topography and internal layering (Robin and others, 1969; Watts and others, 1975; Björnsson, 1981; Bogorodsky and others, 1985). Impulse radar systems were introduced by Watts and others (1975) and have become standard instruments for ice-thickness measurements on glaciers. Several detailed descriptions of suitable systems for temperate ice exist (Sverrisson and others, 1980; Watts and Wright, 1981; Narod and Clarke, 1994; Funk and others, 1995). Seismic reflection data-processing techniques such as migration have been successfully adapted to radio-echo processing, allowing the analysis of complex geometrical structures (Yilmaz, 1987). Some of the recent advances in fieldwork, data processing and interpretation are discussed in Herzfeld and others (1993) and Welch and others (1998).

On Unteraargletscher, Bernese Alps, Switzerland, measurements of ice thickness have a long tradition, the first (unsuccessful) attempt by drilling being made by Agassiz (1847). Reflection seismic and direct-current resistivity measurements have also been used for the same purpose on this glacier (Kreis, 1941; Knecht and Süsstrunk, 1952; Kreis and others, 1952; Röthlisberger and Vögtli, 1967; Sambeth and Frey, 1987a, b). Starting in 1986, the bed topography was for the first time determined by successive radio-echo soundings (Funk and others, 1995). By now a fairly dense net of about 40 profiles has been collected, covering the entire branched glacier system. In this paper, we present new results from

* Present address: British Antarctic Survey, Natural Environment Research Council, Madingley Road, Cambridge CB3 0ET, England. radio-echo soundings on Lauteraar-, Finsteraar- and Unteraargletscher, and discuss various issues related to data processing and basal-topography determination using radio-echo sounding. We concentrate on the particular requirements of a narrow, deep channel shape and a thick temperate ice body as typically found on alpine-type valley glaciers. An independent verification of radio-echo sounding results with boreholes reaching the glacier bed is given.

Finsteraar- and Lauteraargletscher are the two main tributaries of Unteraargletscher (see Fig. 1). They are both roughly $1 \mathrm{~km}$ wide and have about the same surface inclination (approximately $4-5^{\circ}$ ). The steep side-walls indicate a deep valley trough geometry. To determine ice thicknesses in this type of geometrical configuration can be challenging. If the maximum thickness is larger than half of the glacier width, the first arriving reflection usually comes from a section of the bed close to the side-walls. Information on the deeper-lying sections of the bed is derived from laterrecorded segments of the signal. Due to longer travel paths, the attenuation is greater and several different reflections may overlap, necessitating careful data analysis.

\section{INSTRUMENT AND METHODS}

The design of the radar device used in this study is described in Funk and others (1995) and based on Watts and Wright (1981). It is a standard low-frequency type pulse system suitable for radar applications in temperate ice conditions. The instrument's special characteristic is an amplifier enabling penetration through thick temperate ice bodies. Over the last 5 years, various improvements have been made to the original design. New robust and powerful, resistively loaded antennas of 10,20 and $40 \mathrm{~m}$ half-length allow for a choice of accuracy and resolution depending on ice thickness. The receiver unit is connected to a rugged, hand-held, digital sampling portable oscilloscope, and data are downloaded directly to a laptop computer. The oscilloscope is equipped 


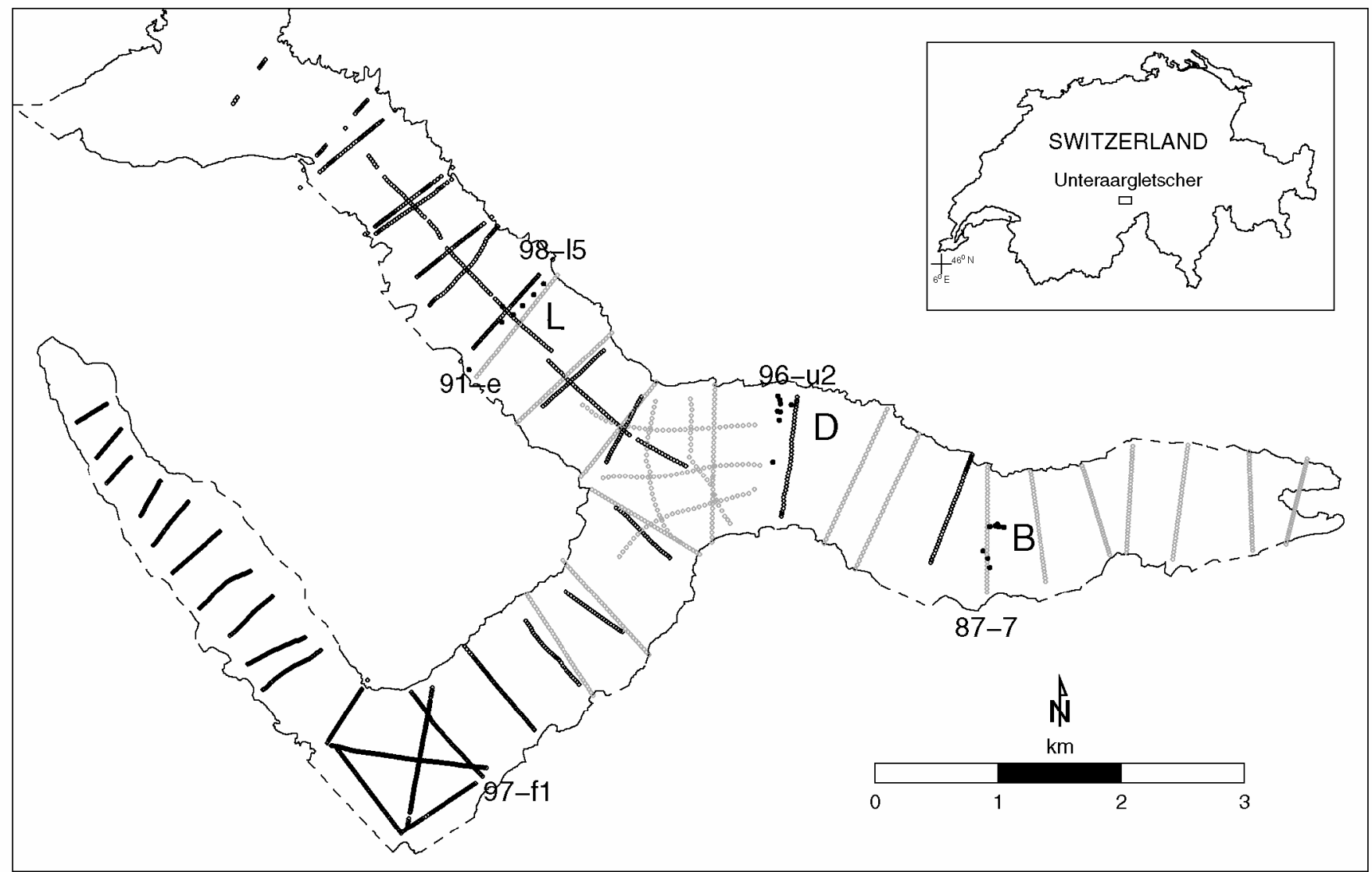

Fig. 1. Map of study area showing location of radar profiles (1987-91, grey; 1996-2002, black) and boreholes (filled circles). Individual profiles referred to in the text are named.

with modern sampling and stacking features and guarantees a recorded signal of high quality. Any extensive data processing is useless if the measured signal does not have enough information content. The equipment is lightweight and consists of a few small individual components, making it well suited for use in alpine environments. The battery packs are the main source of weight. For normal use, the instrument is loaded to two sledges. It is compact enough to be carried in backpacks if needed.

Alpine-type glaciers are usually valley-shaped, and the appropriate approach for mapping the spatial coverage of the glacier bed topographies is by a set of cross-profiles. Assuming reflection along a vertical profile plane only, is, for most cases, a quite acceptable working hypothesis. Longitudinal profiles could in principle provide additional information and be linked with cross-profiles, but in practice such longitudinal profiling has proven to be of limited use because most of the received reflections originate from the side-walls. To avoid spatial aliasing during data processing, a data spacing not larger than about $\lambda / 4$ is required (Yilmaz, 1987; Welch and others, 1998). This is the maximum distance between individual traces not only along the profile, but also between adjacent profiles. Such a short spacing between profiles is, however, unrealistic for most purposes, and in order to map a larger area a trade-off between resolution and spatial coverage must be accepted. Due to high signal attenuation in temperate ice and antenna characteristics, the antennas must be spread out perpendicular to the cross-profile direction (e.g. Arcone and others, 1995) to receive a signal of high quality.

An approach that has often been used to determine the bed geometry from travel-time data is to plot the ellipses of all possible reflection points for each measured travel time, with sender and receiver at the two focal points. This procedure can, however, be misleading. In particular, for deep channels, where multiple reflections must be used, care must be taken not to use too few data points (e.g. Rabus and Echelmeyer, 1997).

In this study, we applied a three-step procedure using the software package Seismic Unix (Cohen and Stockwell, 1996). First the raw measurement data were treated with an automatic gain control to accentuate later-arriving signal segments. High-frequency random noise was then eliminated using a bandpass filter. The last step accounts for the omnidirectional reflected signal and included a migration with a phase-shift procedure. Ice thicknesses were then determined through a time--space transformation of the two-way travel times. The propagation velocity of electromagnetic waves in temperate ice was assumed to be $168 \mathrm{~m} \mu \mathrm{s}^{-1}$ (Glen and Paren, 1975; Robin, 1975; Kovacs and others, 1995). Direct velocity measurements in the field using the common-depth-point method were attempted, but were not successful, due to irregular bed topography. A common-depth-point array requires a nearly surface-parallel bed section not found at the field site. The final step consisted in merging surveyed profile positions with the evaluated ice thicknesses and gaining directly the coordinates of the bed topography.

\section{SOUNDINGS}

After the initial mapping of the lower reaches of Unteraargletscher and, a few years later, of its confluence area, additional measurements were carried out in order to fill some gaps and to extend the coverage to Finsteraar- and Lauteraargletscher. Individual campaigns were always tied to specific 

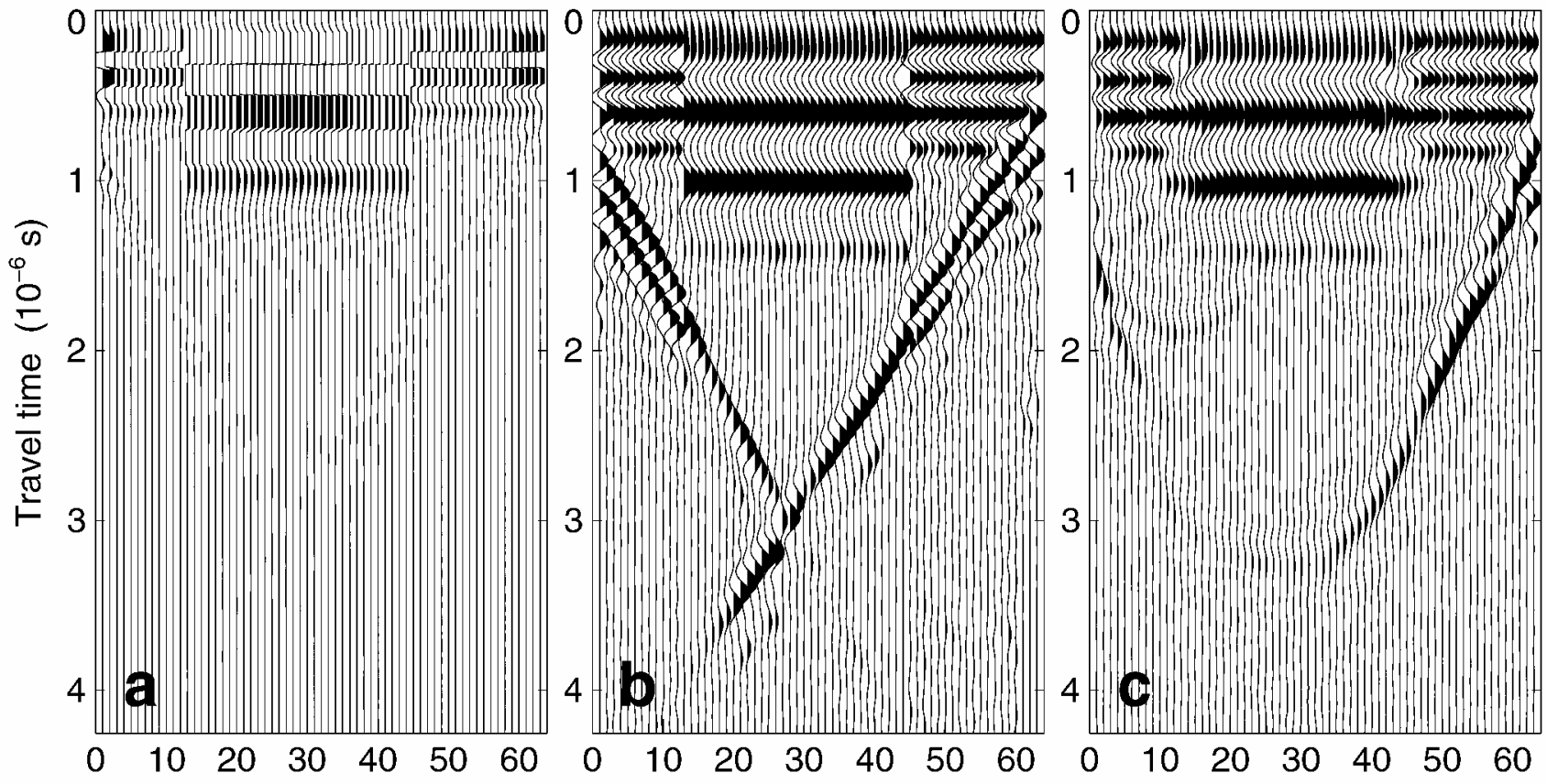

Fig. 2. Profile 97-f1: raw data (a), after gain and filtering (b) and migration (c).

projects and not to a comprehensive mapping of all of the glaciated area. The measurements were started as part of a study of the interaction between the glacier and a scheduled hydrological reservoir (Funk, 1987; Röthlisberger and Funk, 1987). Numerical modeling studies of the flow dynamics of the confluence area (Gudmundsson, 1997; Gudmundsson and others, 1997) and later of the whole glacier (Bauder, 2001a) led to additional radio-echo soundings. All measured profiles are shown in Figure 1. Between 1996 and 2001 the focus has been on closing gaps between individual profiles considered to be too wide, and on extending the coverage further up-glacier. Various conflicts of interpretation have been resolved through additional measurements, and it was recognized that several earlier interpretations in the deep tributaries up-glacier from the confluence area were too shallow (Bauder, 2001a).

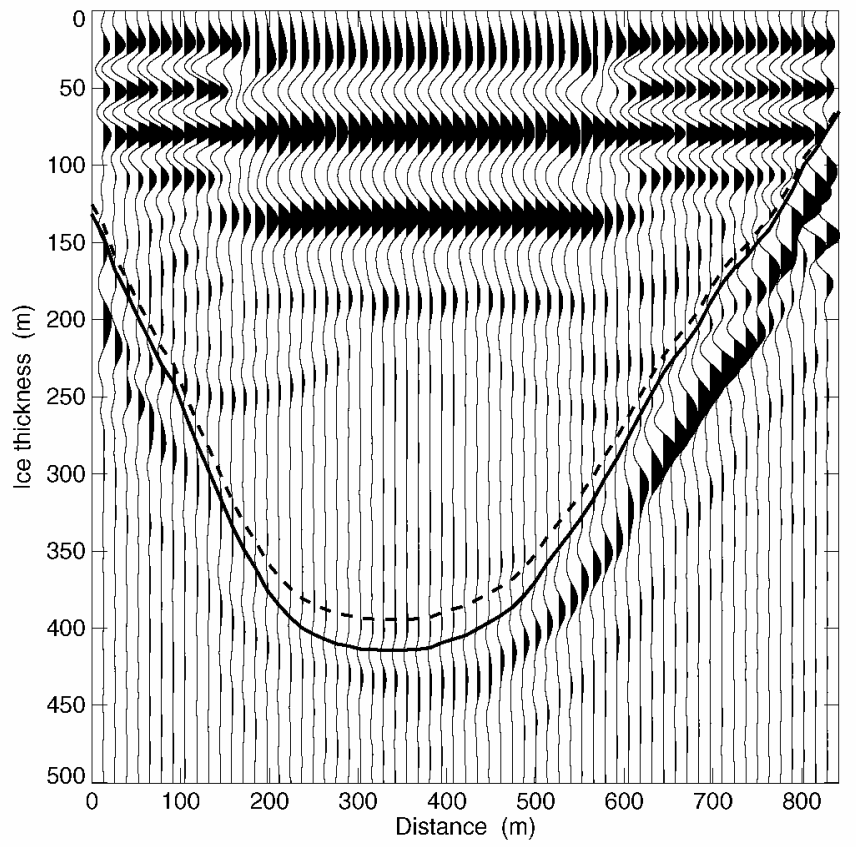

Fig. 3. Comparison of thickness in profile 97-f1 determined by ellipse envelope (dashed line) and 5\% enlarged (solid line), coinciding with the reflections resulting after migration.

\section{RESULTS}

Figure 2 gives an example of the results of different steps of the signal processing for profile 97-f1 (see Fig. 1). This profile is on Finsteraargletscher and can be considered typical for the situation up-glacier of the confluence area where the ice thicknesses are in general larger than half of the glacier width. In the raw data (Fig. 2a), the signal of the direct airwave is clearly visible, while bed reflections are hardly identifiable. The positive effect of changing the antennas in the central part of the profile, so as to improve the strength of the reflections, is apparent in the data. After the gain and filtering step has been performed (Fig. 2b) the information in the later segments of the signal appears much more clearly, and the first and second reflections result in a typical bowtie pattern. Different migration procedures were tested, and the best results obtained using a phase-shift migration (Fig. 2c). After the migration step, the reflection horizon of the glacier bed can clearly be followed, even for the deepest part of the bed. On the lefthand side, the less clear reflections suggest the presence of an almost vertical cliff or some discontinuities perpendicular to the profile plane.

For the same profile, the corresponding ellipses were plotted and analyzed, and compared with the migrated profile (Fig. 3). The determined envelope, drawn as a dashed line, gives smaller ice thicknesses than the migrated data. Only by arbitrarily increasing the thicknesses based on the envelope of the ellipses by $5 \%$ (solid line) does one obtain ice thicknesses that agree well with the migrated result. Care must be taken in interpreting the individual wiggles in Figure 3 directly, as the amplitudes of the primary impulse of the reflections turned out to be smaller than subsequent ones.

The discrepancy between envelope technique and migration processing is worrying, and led us to remeasure previously investigated sections above the confluence area with shorter trace spacing than had been done earlier. Re-analysis of this denser dataset using the simple envelope technique now led to ice thicknesses which were essentially identical to the previous migrated results. Only the abovedescribed method, with migration, obtained clearly defined 


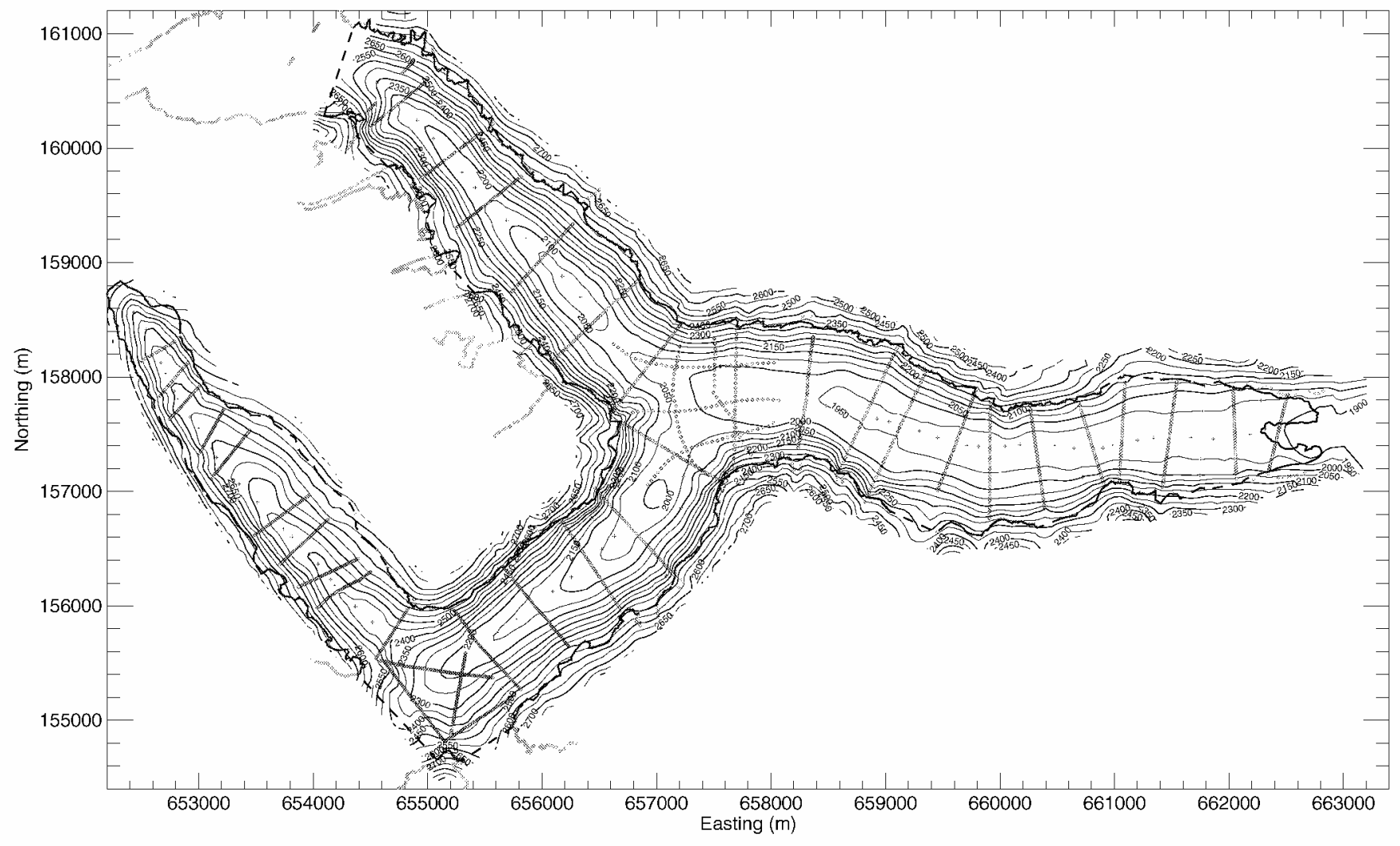

Fig. 4. Contour map of glacier-bed topography of Unteraargletscher. Contour interval is $50 \mathrm{~m}$. Coordinates are in metres and correspond to the official Swiss coordinate system.

reflections in the central and deepest part of each profile. In both tributaries the largest thickness values of 400-450 m are found at $0.5-1 \mathrm{~km}$ above the confluence area.

Figure 4 shows a contour plot of bed topography using all the data so far available. Interpolating the very unevenly scattered input data to a uniformly spaced grid is a challenging task. Applied directly to the dataset, most standard interpolation routines give spurious results. Our approach is based on using continuously differentiable, quintic polynomial interpolation functions in two variables (Akima, 1978). In addition to the radar sounding data, we included four different types of information:

(1) The glacier boundary was determined photogrammetrically, and only outcropping rocks were used. An important aspect is that the boundary was not considered as a discontinuity.

(2) A digital elevation model (DEM) of the surrounding terrain was also included in the dataset. For a flanking stripe the high-precision Swiss DEM in 25 m resolution was used ( $\mathrm{L}+\mathrm{T}, 1993)$.

(3) As a working hypothesis, it was assumed that in flow direction the gradients are moderate. Between the deepest locations on adjacent profiles, two linearly interpolated points were introduced.

(4) Where the contour plot was determined by visual inspection to be less than satisfying, some fine tuning was done in an iterative manner by manually setting the thickness at a limited number of locations based on a visual interpolation of the original data.

The first two steps influenced the result primarily in the border area. The third step yielded the main enhancement of the procedure, while the fourth led to a marginal refine- ment and did not significantly affect the resulting ice-thickness distribution.

Table 1. Borehole comparison statistics

\begin{tabular}{|c|c|c|c|}
\hline Borehole & $\begin{array}{c}\text { Depth } \\
\text { m }\end{array}$ & $\begin{array}{c}\text { Difference } \\
\mathrm{m}\end{array}$ & $\begin{array}{c}\text { Distance } \\
\mathrm{m}\end{array}$ \\
\hline B96-B & 255.5 & -2.4 & 67.9 \\
\hline B97-1 & 262.0 & -6.3 & 82.4 \\
\hline B97-2 & 254.0 & 1.8 & 81.3 \\
\hline B99-01 & 263.5 & -22.4 & 19.6 \\
\hline B99-03 & 255.2 & -14.0 & 22.1 \\
\hline B99-02 & 251.0 & -9.7 & 24.4 \\
\hline B99-10 & 247.3 & -0.4 & 92.4 \\
\hline B99-04 & 252.0 & -5.1 & 95.9 \\
\hline B99-05 & 231.0 & 13.6 & 101.6 \\
\hline B99-06 & 248.6 & -4.3 & 104.2 \\
\hline B99-07 & 215.6 & 16.5 & 32.9 \\
\hline B99-08 & 178.5 & 29.2 & 5.6 \\
\hline B99-09 & 146.0 & 27.6 & 25.7 \\
\hline D00-500 & 114.0 & -49.3 & 115.2 \\
\hline D00-501 & 157.0 & -62.1 & 137.3 \\
\hline D00-502 & 187.0 & -56.8 & 129.1 \\
\hline D00-503 & 211.0 & -15.9 & 142.5 \\
\hline D00-504 & 247.0 & -51.9 & 119.4 \\
\hline D00-505 & 260.0 & -23.0 & 120.4 \\
\hline D00-552 & 188.0 & -42.3 & 41.9 \\
\hline D00-510 & 343.0 & -11.0 & 108.1 \\
\hline $101-1$ & 120.0 & -4.4 & 75.9 \\
\hline $101-2$ & 243.0 & 3.8 & 74.9 \\
\hline $101-3$ & 380.0 & 0.7 & 67.9 \\
\hline $101-4$ & 425.0 & 17.3 & 59.9 \\
\hline $101-5$ & 398.0 & 14.4 & 32.2 \\
\hline $101-7$ & 400.0 & 30.1 & 48.6 \\
\hline $\begin{array}{l}\text { Mean } \\
\text { rms }\end{array}$ & 249.4 & $\begin{array}{c}-8.4 \\
26.7\end{array}$ & 75.2 \\
\hline
\end{tabular}



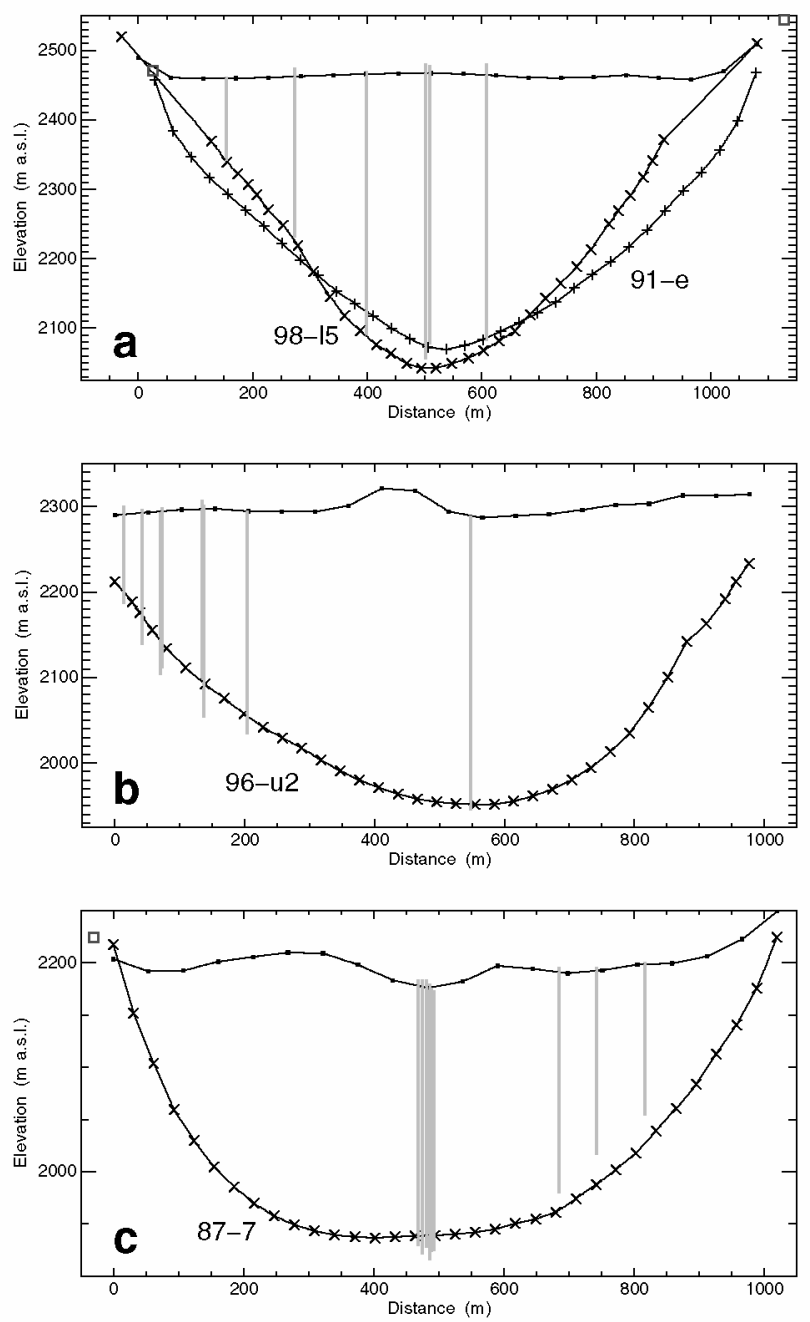

Fig. 5. Comparison of radio-echo results with boreholes. Transects $L(a), D(b)$ and $B(c)$ as seen in flow direction. Surface elevation is dated from fall 1999.

Another often-used approach is to interpolate the ice thickness and determine the bed topography by subtracting the thickness from the surface instead of the bed topography directly. The advantage of this approach is that the ice thickness sometimes varies less strongly than the bedrock topography. This approach, however, is unsuitable for Unteraargletscher because of its high surface roughness (Bauder, 2001b).

Several boreholes to the bed have been drilled during the last 5 years at different locations on the glacier (see Fig. 1). We evaluated 27 boreholes with precisely surveyed positions and reliable thickness values. During the borehole campaign 2000 the shape of the new drilled boreholes was surveyed thoroughly by inclinometry. We found a fair agreement with measured thickness during drilling, and small vertical deviations. The range of differences in ice-thickness values obtained by these two methods is listed in Table 1. The table also lists the distance between each borehole and the closest point in the input dataset of the interpolation, and the overall mean and rms of the differences. The mean of the difference is $-8.4 \mathrm{~m}$, while the rms is $27 \mathrm{~m}$. Only weak evidence exists that in shallow areas drillings tend to be deeper while in deeper areas the drillings may have reached the bed too early. The evaluated differences between drillings and interpolation show no dependence on the depth or the distance to the closest point in the input dataset.

In some instances, the comparison between individual borehole depths and the radio-echo thickness required considerable spatial interpolation of the radio echo. A more direct comparison can be made where a group of boreholes are close to a radar profile. In areas B, D and L (see Fig. 1), several boreholes lie on a transect in close proximity to a radar profile. The borehole depths were projected to the profile plane (Fig. 5). In general, a better agreement between borehole depths and the radio-echo sounding is found for these boreholes.

\section{Area B}

Soundings of profile 87-7 dating from 1987. No digital registration was possible, and analysis is based on the envelope technique. Some of the clustered boreholes in the center lie up to $100 \mathrm{~m}$ further down-glacier.

\section{Area D}

All boreholes lie 125-150 m up-glacier of the profile plane. Artifacts in the data due to antenna defects substantially reduced the quality of the measurements on profile 96-u2. No digital data were recorded and saved. Only first reflections were used for the interpretation. Comparison shows the largest differences (see Table 1) between drilling and interpolation bed elevations.

\section{Area L}

The two neighboring radio-echo sounding profiles 91-e and 98-15, dating from 1991 and 1998, respectively, were projected onto an intermediate plane. This profile on Lauteraargletscher represents a typical situation encountered on this glacier and on Finsteraargletscher, of a deep and narrow channel with steep facing side-walls. The previously discussed differences in results based on different analysis techniques are clearly visible (Fig. 5a). The earlier interpretation of profile 91-e is based on an iterative method of calculated theoretical travel times for a given profile surface, and continuously adapted to the measurements until a threshold is reached (Funk and others, 1995). The analysis of measurements 98-15 follows the fully digital interpretation as described above. The smallest deviations between drilling and radio-echo sounding appear in this area.

\section{DISGUSSION AND CONGLUSIONS}

The main aim of this study was an area-wide determination of the thickness across the glaciated area, and some reduction in achievable resolution was accepted. For this purpose, the chosen strategy with a set of cross-profiles and migration only in profile plane was adequate. Additional use of longitudinal profiles did not work in the existing topographical situation due to difficulties in determining the true location of the reflections. Information on the deepest sections could rarely be obtained from longitudinal profiling. Only crossprofiling is to be recommended.

The analysis showed that dense measurements (spacing not larger than $\lambda / 4$ ) are the most important single requirement for a successful bed determination. To determine the bed in the deepest part of the profiles required not just the inclusion of secondary reflections, but rather a complete migration using all of the information content in the signal. The simple envelope technique uses only a small part of the available information. The propagation of an electromagnetic 
signal through several-hundred-meter thick, temperate ice results in considerable signal attenuation. Nevertheless, the instrument used and the applied measurement procedure proved to be an efficient and powerful tool for radio-echo sounding surveys on thick, temperate valley glaciers.

In the tributaries Lauteraar- and Finsteraargletscher, the new ice-thickness map shows deeper central bed topography than earlier mapping results based on radio-echo soundings (Funk and others, 1995) or reflection seismic surveys (Knecht and Süsstrunk, 1952; Kreis and others, 1952). In this area, the relief is characterized by a roughly $900 \mathrm{~m}$ wide, $400 \mathrm{~m}$ deep channel with steep side-walls. The existence of riegels at the entrance of the confluence area - still apparent in the map, but less so than in previous ones (Funk and others, 1995) - is questionable. Even the recent measurements along cross-profiles over the riegels have proved inconclusive. The small and remote steep firn area is still lacking in the determined map. Highly crevassed icefalls and omnidirectional reflections have so far prevented accurate ice-thickness determination in this area.

In general, ice-thickness determination by hot-water drilling compared quite well with the radar-sounding results. The agreement is excellent for the uppermost area on Lauteraargletscher (area L), but is somewhat less satisfying for the two lower areas B and D on Unteraargletscher where the measurements are older and of poorer quality. In area $\mathrm{L}$, the drillings and the repeated radio-echo soundings were made purposely along the same transverse profile. For area D, most of the differences are presumably due to interpolation errors. The reason for the observed differences in area $\mathrm{B}$ is not clear and remains to be investigated in more detail. There are several indications that below the confluence area the bed is soft (Sambeth and Frey, 1987b; Gudmundsson and others, 1999). Possibly, the underlying sediment layer and a potential debris-rich basal ice layer influence drillings and radio-echo soundings differently.

\section{ACKNOWLEDGEMENTS}

This research was partly funded by Swiss National Science Foundation grant 21-47095.96 and 20-53561.98. The manuscript was written while A.B. held a postdoctoral position at the Department of Geology and Geophysics, University of Wisconsin-Madison, U.S.A. Most of the surveying was done by H. Bösch. A number of people assisted with the fieldwork. Important logistic support was provided by the Swiss Army. The authors thank the editor, A. C. Fowler, and two anonymous reviewers for helpful comments.

\section{REFERENCES}

Agassiz, L. 1847. Système glaciaire ou recherches sur les glaciers, leur mécanisme, leur ancienne extension et le rôle qu'ils ont joué dans l'histoire de la terre. Première partie. Nouvelles études et expériences sur les glaciers actuels, leur structure, leur progression et leur action physique sur le sol. Paris, Victor Masson.

Akima, H. 1978. A method of bivariate interpolation and smooth surface fitting for irregularly distributed data points. ACM Trans. Math. Software, $4(2), 148-159$.

Arcone, S. A., D. E. Lawson and A. J. Delaney. 1995. Short-pulse radar wavelet recovery and resolution of dielectric contrasts within englacial and basal ice of Matanuska Glacier, Alaska, U.S.A. 7. Glaciol., 41(137), 68-86.

Bauder, A. 200la. Bestimmung der Massenbilanz von Gletschern mit Fernerkundungsmethoden und Fliessmodellierungen. (Ph.D. thesis, Eidgenössischen Technischen Hochschule Zürich, No. 14110.)

Bauder, A. 2001b. Bestimmung der Massenbilanz von Gletschern mit Fernerkundungsmethoden und Fliessmodellierungen: eine Sensitivitätsstudie auf dem Unteraargletscher. Eidg. Tech. Hochschule, Zürich. Versuchsanst. Wasserbau, Hydrol. Glaziol. Mitt. 169.

Björnsson, H. 1981. Radio-echo sounding maps of Storglaciären, Isfallsglaciären and Rabots glaciär, northern Sweden. Geogr. Ann., 63A(3-4), 225-231.

Bogorodsky, V.V., C. R. Bentley and P. E. Gudmandsen. 1985. Radioglaciology. Dordrecht, etc., D. Reidel Publishing Co.

Cohen, J. K. and J.W. Stockwell. 1996. CWP/SU: Seismic Unix Release 29: a free package for seismic research and processing. Golden, CO, Colorado School of Mines. Centre for Wave Phenomena.

Funk, M. 1987. Schlussbericht über die Sondierungen 1986. Zürich, Versuchsanstalt für Wasserbau, Hydrologie und Glaziologie der Eidgenössischen Technischen Hochschule Zürich. (Im Auftrag der Kraftwerke Oberhasli AG, Innertkirchen. Bericht 20.4.)

Funk, M., G. H. Gudmundsson and F. Hermann. 1995. Geometry of the glacier bed of the Unteraarglacier, Bernese Alps, Switzerland. Z. Gletscherkd. Glazialgeol., 30, 1994, 187-194.

Glen, J.W. and J. G. Paren. 1975. The electrical properties of snow and ice. F. Glaciol., 15(73), 15-38.

Gudmundsson, G. H. 1997. Ice deformation at the confluence of two glaciers investigated with conceptual map-plane and flowline models. F. Glaciol., 43(145), 537-547.

Gudmundsson, G. H., A. Iken and M. Funk. 1997. Measurements of ice deformation at the confluence area of Unteraargletscher, Bernese Alps, Switzerland. 7. Glaciol., 43(145), 548-556.

Gudmundsson, G. H., A. Bauder, M. Lüthi, U. H. Fischer and M. Funk. 1999. Estimating rates of basal motion and internal ice deformation from continuous tilt measurements. Ann. Glaciol., 28, 247-252.

Herzfeld, U. G., M. G. Eriksson and P. Holmlund. 1993. On the influence of kriging parameters on the cartographic output - a study in mapping subglacial topography. Math. Geol., 25(7), 881-900.

Knecht, H. and A. Süsstrunk. 1952. Bericht über die seismischen Sondierungen der Schweizerischen Gletscherkommission auf dem Unteraargletscher, 1936-1950. Sion, Grande Dixence S.A. (Bericht 512.)

Kovacs, A., A. J. Gow and R. M. Morey. 1995. The in-situ dielectric constant of polar firn revisited. Cold Reg. Sci. Technol., 23(3), 245-256.

Kreis, A. 1941. Ergebnisse der seismischen Eistiefenbestimmungen auf dem Unteraargletscher. Verh. Schweiz. Naturf. Gesells. , 121, 99-100. (Jahresversammlung.)

Kreis, A., R. Florin and A. Süsstrunk. 1952. Die Ergebnisse der seismischen Sondierungen des Unteraargletschers 1936-1950. Verh. Schweiz. Naturf. Gesells., 132, 124-126. (Jahresversammlung.)

L+T. 1993. Digitales Höhenmodell DHM25. Wabern, Switzerland, Bundesamt für Landestopographie. (Produktinformation.)

Narod, B. B. and G. K. C. Clarke. 1994. Miniature high-power impulse transmitter for radio-echo sounding. F. Glaciol., 40(134), 190-194.

Rabus, B.T. and K. A. Echelmeyer. 1997. The flow of a polythermal glacier: Mc Call Glacier, Alaska, U.S.A. 7. Glaciol., 43(145), 522-536.

Robin, G. de Q. 1975. Velocity of radio waves in ice by means of a bore-hole interferometric technique. 7. Glaciol., 15(73), 151-159.

Robin, G. de Q., S. Evans andJ.T. Bailey. 1969. Interpretation of radio echo sounding in polar ice sheets. Philos. Trans. R. Soc. London, Ser. A, 265(1166), 437-505.

Röthlisberger, H. and M. Funk. 1987. Sondierungen Unteraargletscher und Gletscherrückzug. Zürich, Versuchsanstalt für Wasserbau, Hydrologie und Glaziologie der Eidgenössischen Technischen Hochschule Zürich. (Im Auftrag der Kraftwerke Oberhasli AG, Innertkirchen. Bericht 20.6.)

Röthlisberger, H. and K. Vögtli. 1967. Recent D.C. resistivity soundings on Swiss glaciers. F. Glaciol., 6(47), 607-621.

Sambeth, U. and P. Frey. 1987a. Auswertung der Geoelektrischen Messungen im unteren Gebiet der Zunge des Unteraargletschers. Zug, Switzerland. Peter Frey, Geolog. Expertisen. (Bericht 87107.)

Sambeth, U. and P. Frey. 1987b. Geophysikalische Messungen zur Abklärung des Aufbaus des Unteraargletschers, der unterliegenden Sedimente und der Felsoberkante. Zug, Switzerland. Peter Frey, Geolog. Expertisen. (Bericht 87102.

Sverrisson, M., Æ. Jóhannesson and H. Bjornsson. 1980. Radio-echo equipment for depth sounding of temperate glaciers. F. Glaciol., 25(93), 477-486.

Watts, R. D. and D. L. Wright. 1981. Systems for measuring thickness of temperate and polar ice from the ground or from the air. F. Glaciol., 27(97), 459-469.

Watts, R. D., A.W. England, R. S. Vickers and M. F. Meier. 1975. Radioecho sounding on South Cascade Glacier, Washington, using a longwavelength, mono-pulse source. [Abstract.] 7. Glaciol., 15(73), 459-461.

Welch, B. C., W. T. Pfeffer, J. T. Harper and N. F. Humphrey. 1998. Mapping subglacial surfaces of temperate valley glaciers by two-pass migration of a radio-echo sounding survey. F. Glaciol., 44(146), 164-170.

Yilmaz, Ö. 1987. Seismic data processing. Third edition. Tulsa, OK, Society of Exploration Geophysicists. (Investigations in Geophysics 2. 